\title{
Influence of bicortical techniques in internal connection placed in premaxillary area by 3D finite element analysis
}

Fellippo Ramos Verri, Ronaldo Silva Cruz, Cleidiel Aparecido Araújo Lemos, Victor Eduardo de Souza Batista, Daniel Augusto Faria Almeida, Ana Caroline Gonçales Verri \& Eduardo Piza Pellizzer

To cite this article: Fellippo Ramos Verri, Ronaldo Silva Cruz, Cleidiel Aparecido Araújo Lemos, Victor Eduardo de Souza Batista, Daniel Augusto Faria Almeida, Ana Caroline Gonçales Verri \& Eduardo Piza Pellizzer (2017) Influence of bicortical techniques in internal connection placed in premaxillary area by 3D finite element analysis, Computer Methods in Biomechanics and Biomedical Engineering, 20:2, 193-200, DOI: 10.1080/10255842.2016.1209188

To link to this article: https://doi.org/10.1080/10255842.2016.1209188

Published online: 13 Jul 2016.

Submit your article to this journal $\pi$

Щ Article views: 111

View Crossmark data $\subset$

Citing articles: 2 View citing articles $\square$ 


\title{
Influence of bicortical techniques in internal connection placed in premaxillary area by 3D finite element analysis
}

\author{
Fellippo Ramos Verria, Ronaldo Silva Cruz ${ }^{a}$, Cleidiel Aparecido Araújo Lemos ${ }^{a}$, Victor Eduardo de Souza Batista ${ }^{a}$, \\ Daniel Augusto Faria Almeidac, Ana Caroline Gonçales Verrib and Eduardo Piza Pellizzer ${ }^{\mathrm{a}}$
}

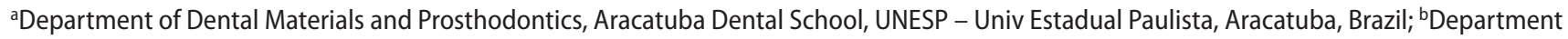
of Pediatric and Community Dentistry, Aracatuba Dental School, UNESP - Univ Estadual Paulista, Aracatuba, Brazil; 'Department of Operative Dentistry, School of Dentistry, Federal University of Alfenas - UNIFAL-MG, Alfenas, Brazil

\begin{abstract}
The aim of study was to evaluate the stress distribution in implant-supported prostheses and peri-implant bone using internal hexagon $(\mathrm{IH})$ implants in the premaxillary area, varying surgical techniques (conventional, bicortical and bicortical in association with nasal floor elevation), and loading directions $\left(0^{\circ}, 30^{\circ}\right.$ and $\left.60^{\circ}\right)$ by three-dimensional (3D) finite element analysis. Three models were designed with Invesalius, Rhinoceros 3D and Solidworks software. Each model contained a bone block of the premaxillary area including an implant $(\mathrm{IH}, \varnothing 4 \times 10 \mathrm{~mm})$ supporting a metalceramic crown. $178 \mathrm{~N}$ was applied in different inclinations $\left(0^{\circ}, 30^{\circ}, 60^{\circ}\right)$. The results were analyzed by von Mises, maximum principal stress, microstrain and displacement maps including ANOVA statistical test for some situations. Von Mises maps of implant, screws and abutment showed increase of stress concentration as increased loading inclination. Bicortical techniques showed reduction in implant apical area and in the head of fixation screws. Bicortical techniques showed slight increase stress in cortical bone in the maximum principal stress and microstrain maps under $60^{\circ}$ loading. No differences in bone tissue regarding surgical techniques were observed. As conclusion, nonaxial loads increased stress concentration in all maps. Bicortical techniques showed lower stress for implant and screw; however, there was slightly higher stress on cortical bone only under loads of higher inclinations $\left(60^{\circ}\right)$.
\end{abstract}

\section{ARTICLE HISTORY}

Received 24 February 2016

Accepted 30 June 2016

\section{KEYWORDS}

Dental implants; biomechanics; stress distribution; finite element analysis

\section{Introduction}

The replacement of teeth by implant-supported prosthesis has been considered a predicable treatment option. Re-establishment of the masticatory and aesthetic function, especially in maxillary anterior region, is a great challenge because of the need for aesthetics replacement, and tooth loss may affect the self-esteem of patients, being more common performing the immediate provisional aesthetics (Cooper et al. 2014). Thus, stress distribution in maxillary anterior should be appropriate in order to avoid masticatory overload that can compromise the physiological bone limits (Goodacre et al. 2003).

In the anterior region of the maxilla, there are some limitations to using implants with desirable length, such as the amount of remaining bone and the proximity to anatomical structures, requiring different approaches of surgical techniques, as nasal floor elevation for the placement of implants with greater length (Mazor et al. 2012; Lorean et al. 2014; Garcia-Denche et al. 2015), since short implants may compromise the osseointegration and primary stability (Baggi et al. 2008; Lemos et al. 2016).

Another alternative is the bicorticalized technique that favoring the primary stability increasing the lock in the apical region, being indicated mainly in immediate implants (Ahn et al. 2012). However, there is an absence of studies that evaluate influence of different surgical techniques in the premaxillary area.

Thus, the aim of study was to evaluated the stress distribution in implant-supported prostheses and peri-implant bone using internal hexagon (IH) implants in the premaxilla area, varying surgical techniques (conventional, bicortical and bicortical in association with nasal floor elevation), and loading directions $\left(0^{\circ}, 30^{\circ}\right.$ and $\left.60^{\circ}\right)$ by (three-dimensional) 3D finite element analysis (FEA). The null hypotheses tested were: (1) There is no difference to stress distribution on fixation screws for different surgical techniques; (2) There is qualitative difference to stress distribution on cortical bone for different surgical techniques around implant neck. 


\section{Materials and methods}

\section{Experimental design}

This research was developed considering two factors: surgical techniques at three levels (conventional, bicortical and bicortical in association with nasal floor elevation $)$ and three conditions ofload $\left(0^{\circ}, 30^{\circ}\right.$ and $\left.60^{\circ}\right)($ Verri et al. 2015).

\section{Modelling}

3D models were created representing a section of premaxillary bone of the upper central incisor with one implant and a cemented crown, being simulated in each type of surgical technique (Table 1). This methodology follows previous studies (Moraes et al. 2015; Santiago et al. 2016; Verri et al. 2016).

The simulation of the bone section was composed of trabecular bone surrounded by $1 \mathrm{~mm}$ of cortical bone layer since the type of bone is found in the maxillary anterior (Lekholm \& Zarb 1985). The bone was obtained from the sagittal section by computerized tomography of the upper central incisor with InVesalius 3.0 software (CTI, Campinas, SP, Brazil) and surface simplification with Rhinoceros 4.0 software (NURBS Modeling for Windows, Seattle, WA, USA).

The crown design was performed after a 3D scan (MDX-20w, Roland DG, SP, Brazil) of an upper central incisor artificial (Manequim Odontológicos Marília, Marília, SP, Brazil). The design of components and implants were obtained from a model providing IH design (Conexão Sistema de Prótese Ltda, Arujá, SP, Brasil), along with the abutment of preparation to receive a cemented crown (cement thickness $0.8 \mathrm{~mm}$ ) (Verri et al. 2015). The implant and crowns were simplified by use of Solidworks 2010 (SolidWorks Corp, Waltham, MA, USA) and Rhinoceros 4.0 software (NURBS Modeling for Windows, Seattle, WA, USA). After simplification, the designs were exported to FEMAP software (Siemens PLM Software Inc., Santa Ana, CA, USA), for generation of meshes by finite element.

The model with conventional placement simulated a bone with $12 \mathrm{~mm}$, being $2 \mathrm{~mm}$ below the internal cortical bone; whereas, the bicortical was simulated as a bone with $10 \mathrm{~mm}$ with apical locking of implant, and the model bicortical in association with nasal floor elevation was simulated at a bone height of $8 \mathrm{~mm}$, being performed at the elevation of $2 \mathrm{~mm}$ simulating the nasal floor elevation, as observed in the studies (Figure 1) (Mazor et al. 2012; Lorean et al. 2014; Garcia-Denche et al. 2015).

The mechanical properties (modulus of elasticity and Poisson's ratio) of each simulated material were incorporated according to the literature (Table 2). All materials were considered isotropic, homogeneous and linearly elastic.

The direction of loads used in the study was according to the study of (Hsu et al. 2007). The applied force was $178 \mathrm{~N}$ at $0^{\circ}, 30^{\circ}$ and $60^{\circ}$ localized $2 \mathrm{~mm}$ below the incisal surface of teeth. The boundary conditions were established as fixed in all axes $(x, y$, and $z)$ at construction lines of bone block near to the apical area of the implant remaining other parts of the model under no restrictions (Figure 1). All contacts were simulated by symmetric weld with excepting the abutment/implant contact which was considered as symmetric contact.

After, the models were exported to NEi Nastran 11.0 (Noran Engineering, Inc., Califórnia, EUA) to results processing. The results were analyzed in FEMAP 11.0 software by visualization of the stress and displacement maps. Bone tissues used maximum principal stress maps as criteria of analysis since they are considered friable materials (Moraes et al. 2015; Santiago et al. 2016). Additionally, microstrain $(\mu \varepsilon)$ was used to verify the cortical bone deformations (Ramos Verri et al. 2015). Stress evaluation of implants, fixation screws and crowns was made using von Mises stress, since this analysis is more appropriated to ductile materials (Verri et al. 2014; Moraes et al. 2015). Furthermore, displacements maps were plotted to comparative qualitative analysis of all models.

\section{Results}

\section{Implant, crown and fixation screw analysis (von Mises stress)}

The analysis of von Mises stress distribution is illustrated in Figure 2, and the maximum and minimum stress in the structures (abutment, fixation screw and implant) can be observed in Table 3. The increase angle of loading tended to overload the walls of the abutments, implants and the fixation screw for all models. Regarding the surgical techniques, the bicortical techniques contributed to reduce stress in the apical region of the implants when compared

Table 1. Specifications of the models used in the present study.

\begin{tabular}{lll}
\hline Models & \multicolumn{1}{c}{ Loads } & Descriptions \\
\hline 1 & & Internal hexagon implant of $\varnothing 4 \times 10 \mathrm{~mm}$ and conventional surgical technique \\
2 & $0^{\circ} / 30^{\circ} / 60^{\circ}$ & $\begin{array}{l}\text { Internal hexagon implant of } \varnothing 4 \times 10 \mathrm{~mm} \text { and bicortical surgical technique } \\
\text { Internal hexagon implant of } \varnothing 4 \times 10 \mathrm{~mm} \text { and bicortical surgical technique associated with nasal floor elevation of } 2 \text { mm }\end{array}$ \\
\hline
\end{tabular}




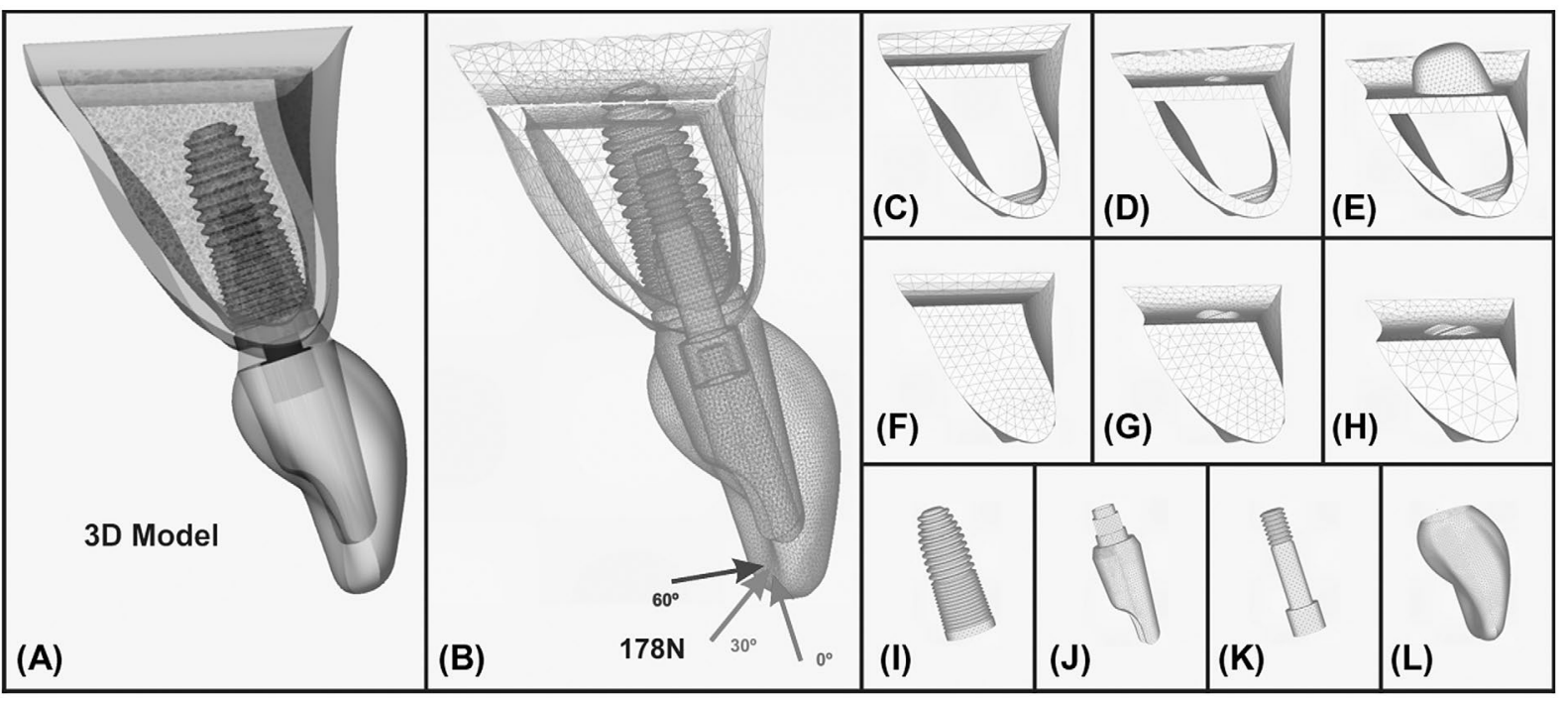

Figure 1. Schematic view of simulated structures and meshes. (A) 3D model; (B) Restriction (yellow lines fixed in $x, y$ and $z$ directions) and loadings; Mesh of cortical bone (C) conventional surgical technique; (D) bicortical surgical technique; (E) bicortical surgical technique associated with nasal floor elevation; Mesh of trabecular bone (F) conventional surgical technique; (G) bicortical surgical technique; (H) bicortical surgical technique associated with nasal floor elevation; Mesh of (I) Implant; (J) Abutment; (K) Fixation screw; (L) Prosthetic crown.

Table 2. Mechanical properties of materials used in the simulation.

\begin{tabular}{lccc}
\hline Structures & Elastic modulus $(\lambda)(\mathrm{GPa})$ & Poisson ratio $(v)$ & Reference \\
\hline Trabecular bone & 1.37 & 0.3 & Moraes et al. (2015) \\
Cortical bone & 13.7 & 0.3 & Moraes et al. (2015) \\
Titanium (implant) & 110.0 & 0.35 & Ramos Verri et al. (2015) \\
NiCr alloy & 206.0 & 0.33 & Ramos Verri et al. (2015) \\
Feldspathic porcelain & 82.8 & 0.35 & Santiago et al. (2016) \\
\hline
\end{tabular}

to conventional technique, slightly reducing the stress in the fixation screws (Figure 2).

\section{Bone tissue analysis (maximum principal stress and microstrain)}

The maximum and minimum stress in the cortical bone tissue can be observed in Table 4 . The analysis showed the increase of stress concentrations on bone tissue as increase of load inclination by maximum principal stress analysis. When compared the surgical techniques, no differences in stress distribution were observed for loads $\left(0^{\circ}\right.$ and $\left.30^{\circ}\right)$. However, for load of $60^{\circ}$ bicortical techniques showed slight increase area of traction stress around the implant, mainly in the interproximal regions of external surface of cortical bone (Figure 3). The contact area of implants and cortical bone for models of bicortical techniques also showed increase of stress in the apical area.

The analysis of $\mu \varepsilon$ under cortical bone tissue showed similar patterns of deformation for all models. The increase of loading direction increased the deformations at buccal region. As in the map of maximum principal stress, no difference was observed between the surgical techniques; however, in the load $60^{\circ}$ was observed slightly concentration area of $\mu \varepsilon$ in the bicortical techniques (Figure 4).

\section{Analysis of general displacement maps}

The increase of load inclination tended to increase the displacement on the analyzed structures. The model of bicortical technique with nasal floor elevation showed lower levels of displacement when compared to the other techniques, mainly on the fixation screw head. The rotation center of the implant/crown set located at apical area on the conventional technique simulated model. This rotation center tended to move to a cervical direction for bicortical techniques, mainly when associated with nasal floor elevation at $30^{\circ}$ and $60^{\circ}$ loads direction (Figure 5).

\section{Discussion}

The first hypothesis tested was rejected, since there was difference between models for von Mises stress in the implant and fixation screw for bicortical techniques (bicortical technique and nasal floor elevation technique) when compared to conventional technique. The second 


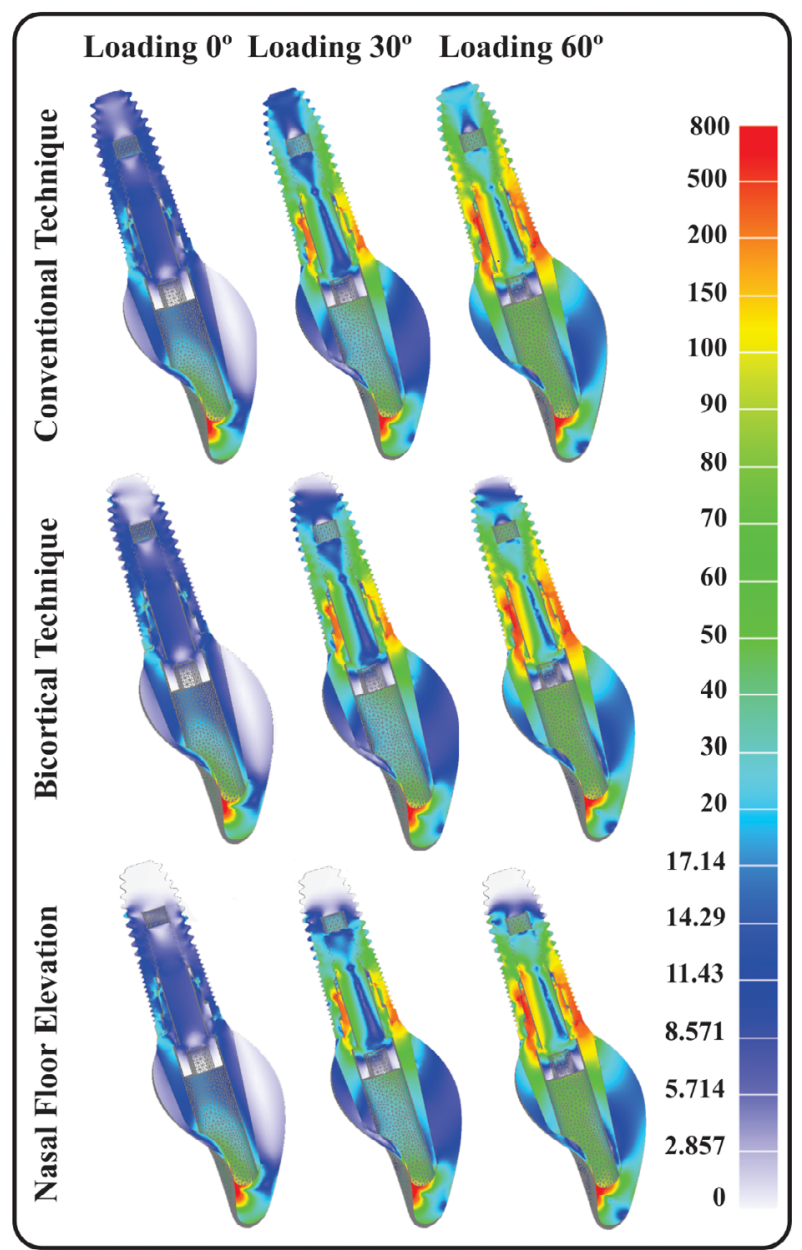

Figure 2. Analysis of von Mises stress of implant, crown and fixation screw.

hypothesis tested was accepted, since there was qualitative difference for stress distribution on cortical bone around implant neck.

The surgical technique may influence significantly the longevity of implant-supported prosthesis. The bicortical technique was related to a significant increase of the removal torque and, consequently, the primary stability of implants (Ahn et al. 2012), improving osseointegration. Displacement maps of this study are in agreement with these standings and showed the tendency of reduction of the movement of strategic areas of the models as implant apex and head of fixation screw.

However, if bicortical or conventional techniques are more adequate for implant placement and implant survival is still controversial. The bicortical technique showed lower survival rate of implants compared to conventional techniques (Ivanoff et al. 2000). Nevertheless, the biomechanical behavior of these techniques is an important point to be considered to help clinicians understand the stress distribution and look for improved predictability for successful implant placement.

Other studies reported biomechanical advantages for bicortical implant placement (Chang et al. 2012; Şeker et al. 2014). The literature suggests that bicortical techniques decrease the stress in the cortical area around the implant neck, since it has features of anchorage in two cortical bone layers (Xiao et al. 2011). In this study, bicortical techniques tended to influence positively to stress reduction in the implant and fixation screw. This fact possibly occurs because bicortical techniques lock the apical area of the implant and relief stress in other areas.

The main advantage for bicortical techniques in this study seems to be the reduction of stress distribution on implant and their components when compared with conventional technique. However, the connection of the implant could influence the results, since other FEA study using external hexagon connection show similar analysis presenting better data for bicortical techniques in the bone around implant neck (Verri et al. 2015). In the present study, IH connection was used, and this connection tends to distribute the stress more centralized and deeper in the implant body, while external hexagon connection concentrates stress mainly around the implant neck and it is related to higher micromovement of its abutment and screw (Maeda et al. 2006). Therefore, this difference of stress distribution between connections could have influenced the results of the present study.

Nevertheless, it is important to emphasize that internal connection has been related favoring reduction of stress concentration around the cortical bone (de Faria Almeida et al. 2014). Furthermore, IH implants have advantages in decreasing the screw-loosening index,

Table 3. Maximum and minimum von Mises stress (MPa) in the abutment, fixation screw and implant.

\begin{tabular}{|c|c|c|c|c|c|c|c|}
\hline \multirow[b]{2}{*}{ Technique } & \multirow[b]{2}{*}{ Loading } & \multicolumn{2}{|c|}{ Abument } & \multicolumn{2}{|c|}{ Screw } & \multicolumn{2}{|c|}{ Implant } \\
\hline & & Maximum & Minimum & Maximum & Mininum & Maximum & Minimum \\
\hline \multirow[t]{3}{*}{ Conventional technique } & $0^{\circ}$ load & 248.78 & 0.49 & 21.03 & 0.05 & 159.55 & 2.29 \\
\hline & $30^{\circ}$ load & 1715.50 & 2.10 & 136.11 & 0.10 & 1084.51 & 0.97 \\
\hline & $60^{\circ}$ load & 3149.98 & 1.73 & 272.10 & 0.33 & 1974.15 & 2.11 \\
\hline \multirow[t]{3}{*}{ Bicortical technique } & $0^{\circ}$ load & 248.89 & 0.33 & 20.61 & 0.06 & 114.82 & 0.06 \\
\hline & $30^{\circ}$ load & 1315.08 & 2.24 & 133.88 & 0.21 & 1037.87 & 0.11 \\
\hline & $60^{\circ}$ load & 3115.45 & 1.70 & 270.41 & 0.35 & 1965.40 & 0.18 \\
\hline \multirow[t]{3}{*}{ Nasal floor elevation technique } & $0^{\circ}$ load & 248.93 & 0.72 & 17.78 & 0.05 & 106.21 & 0.01 \\
\hline & $30^{\circ}$ load & 1723.03 & 2.23 & 128.27 & 0.20 & 992.17 & 0.01 \\
\hline & $60^{\circ}$ load & 3151.49 & 1.16 & 253.16 & 0.29 & 1960.70 & 0.02 \\
\hline
\end{tabular}


Table 4. Maximum and minimum of maximum principal stress (MPa) and microstrain $(\mu \varepsilon)$ on cortical bone tissue.

\begin{tabular}{|c|c|c|c|c|c|}
\hline \multirow[b]{3}{*}{ Technique } & \multirow[b]{3}{*}{ Loading } & \multicolumn{4}{|c|}{ Cortical bone tissue } \\
\hline & & \multicolumn{2}{|c|}{ Maximum principal stress (MPa) } & \multicolumn{2}{|c|}{ Microstrain $(\mu \varepsilon)^{*}$} \\
\hline & & Maximum & Minimum & Maximum & Minimum \\
\hline \multirow[t]{3}{*}{ Conventional technique } & $0^{\circ}$ load & 2.14 & -3.21 & 0.0023 & 0.0001 \\
\hline & $30^{\circ} \mathrm{load}$ & 46.98 & -18.36 & 0.0123 & 0.0003 \\
\hline & $60^{\circ} \mathrm{load}$ & 97.20 & -29.58 & 0.0212 & 0.0005 \\
\hline \multirow[t]{3}{*}{ Bicortical technique } & $0^{\circ} \mathrm{load}$ & 2.33 & -3.51 & 0.0017 & 0.0001 \\
\hline & $30^{\circ} \mathrm{load}$ & 39.10 & -11.74 & 0.0097 & 0.0003 \\
\hline & $60^{\circ} \mathrm{load}$ & 86.87 & -19.87 & 0.0162 & 0.0005 \\
\hline \multirow[t]{3}{*}{ Nasal floor elevation technique } & $0^{\circ}$ load & 2.61 & -3.07 & 0.0021 & 0.0001 \\
\hline & $30^{\circ} \mathrm{load}$ & 46.37 & -17.57 & 0.0124 & 0.0003 \\
\hline & $60^{\circ} \mathrm{load}$ & 95.49 & -30.33 & 0.0214 & 0.0005 \\
\hline
\end{tabular}

*Values $\times 10^{-6}$

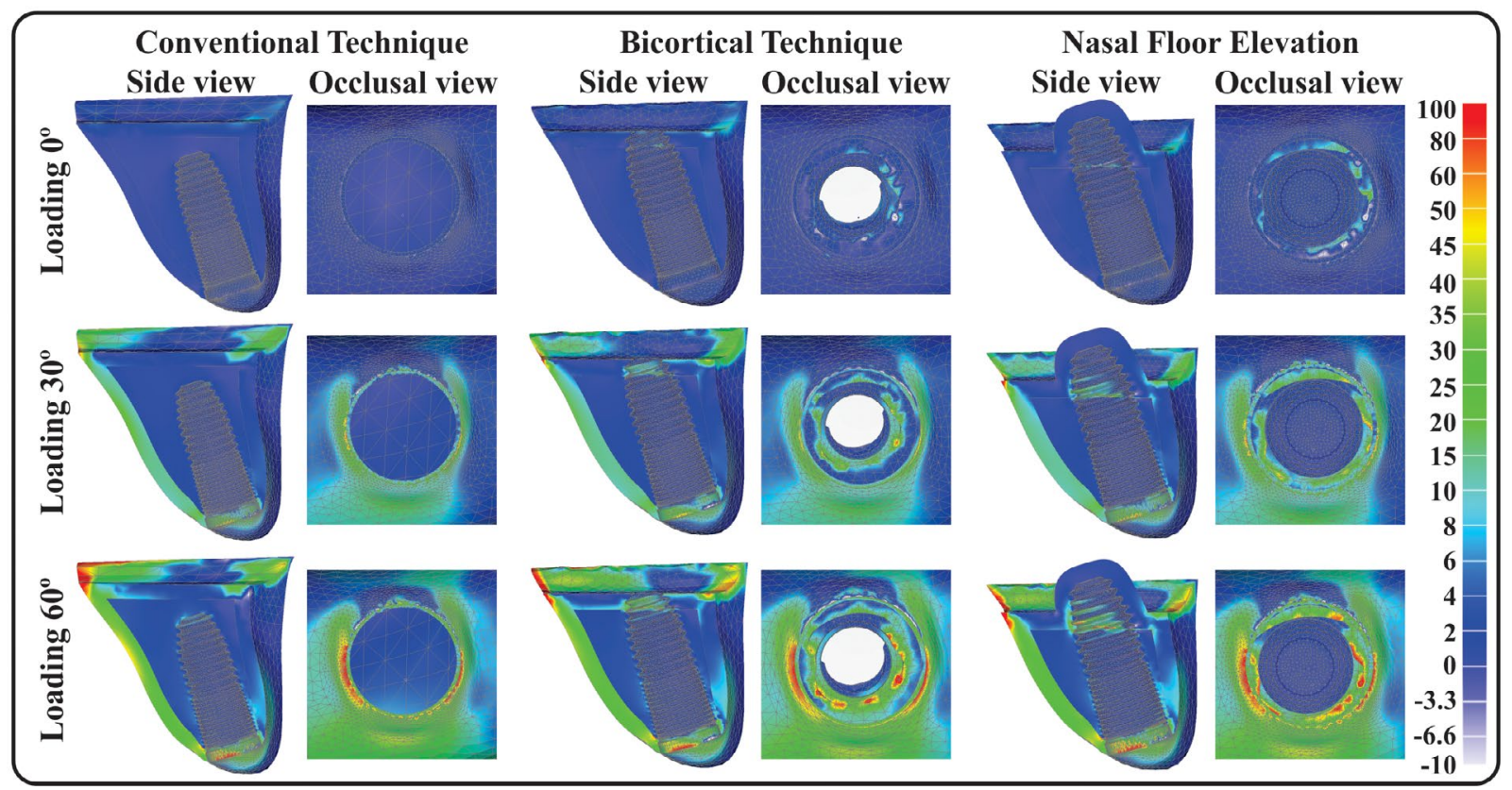

Figure 3. Analysis of maximum principal stress of cortical and trabecular bone (side and occlusal view).

and this complication is the most frequent in implantsupported prosthesis (Binon 2000; Verri et al. 2014).

The screw loosening/fracture has been considered one of the major complications of implant-supported prosthesis (Moraes et al. 2015). Thus, the result showed reduction of stress distribution on fixation screws for bicortical techniques. These techniques could improve the screw-loosening index for these implants. However, it must be highlighted that this data should be interpreted with care, since these implants have thinner side walls that increase the failure risk for non-axial loads (Binon 1996). In this study, the higher stress concentrated in the sidewall of implant in the loadings of $30^{\circ}$ and $60^{\circ}$ reached up to approximately $350 \mathrm{MPa}$. In some situations, the maximum fatigue resistance coefficient of 240-550 MPa was considered to cause a fracture of the implant (Verri et al. 2014).

The stress analysis of bone tissue is important, since an overload that exceeds the physiological limits of bone could compromise the longevity of implant rehabilitation stimulating bone resorption (de Faria Almeida et al. 2014). Papavasiliou et al. 1996 described that the ultimate strength of human cortical bone ranges from 72 to $76 \mathrm{MPa}$ in traction and from 140 to $170 \mathrm{MPa}$ in compression, and the results in this study presented stress on cortical bone below these values; however, some issues should be taken into account, since the models simulated in FEA may present difference in number of nodes/elements, loads/ boundary conditions and material properties, and this may have influenced the results in the stress distribution. In this way, all results observed in the FEA studies could be interpreted with caution, and the data should be evaluated by relative comparisons. Regarding the microstrain, Frost (2003) reported that the acceptable limit for bone tissue are of $3000 \mu \varepsilon$ and, in this study, the models with non-axial loading $\left(30^{\circ}\right.$ and $\left.60^{\circ}\right)$ showed values above the recommended in the buccal, regardless of the technique 


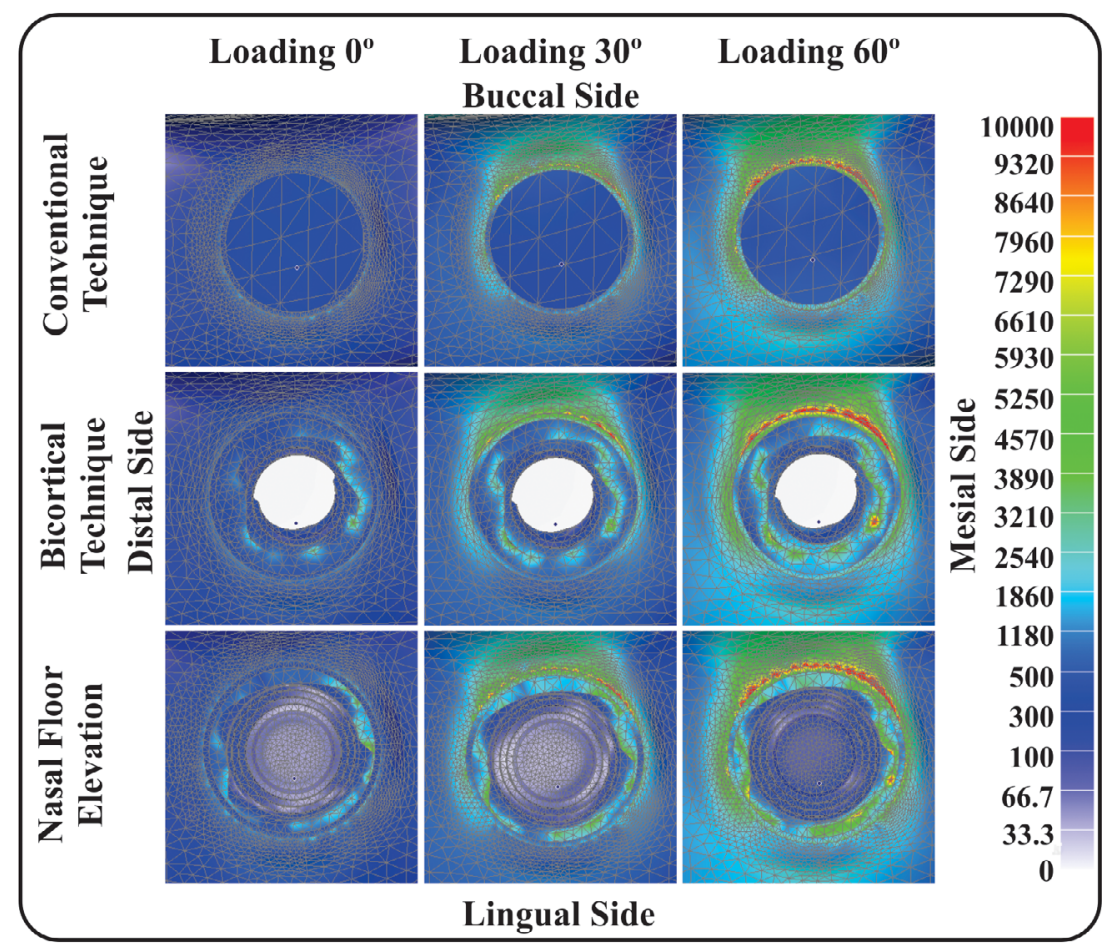

Figure 4. Analysis of microstrain $(\mu \varepsilon)$ criteria of cortical bone.

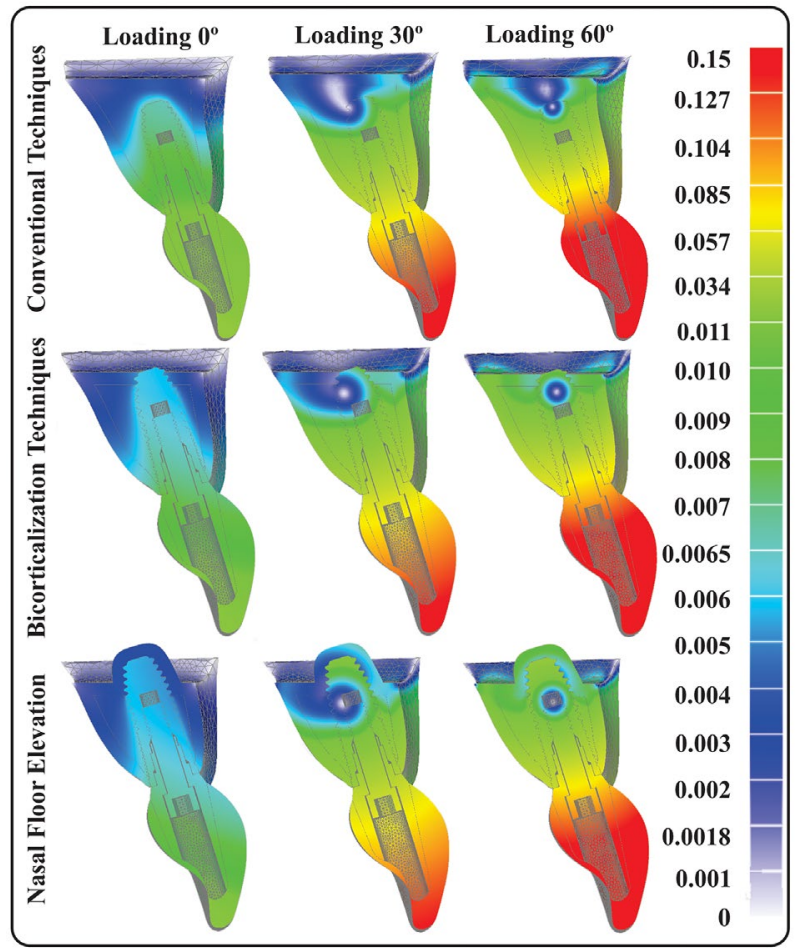

Figure 5. Analysis of displacement of implant, crown, fixation screw, cortical and trabecular bone.

used. Thus, considering these facts, oblique loads could influence the bone resorption, corroborating with other studies (de Faria Almeida et al. 2014; Verri et al. 2014; Ramos Verri et al. 2015), since under off-axis loading conditions, the greater overload of stress around bone tissue was observed. Extrapolating these results to the diary clinics indicates some careful after the installation of the prostheses performing correct occlusal adjustment and avoiding overloading on bone that could undermine the longevity of rehabilitation (Verri et al. 2014).

The finite element method has been used with property for biomechanical analysis in dentistry. However, some limitations should be related to the methodology, as being a computer simulation, linearity elastic analysis, bone tissue considered isotropic and homogenous, and static occlusal loading (Huang et al. 2011). However, this analysis, when combined with trial clinical studies, could serve as a guideline for use of the clinicians in implant dentistry.

Furthermore, some studies used the bone graft after nasal floor elevations to bone regeneration (Mazor et al. 2012; Garcia-Denche et al. 2015), and these bones can not present the same qualities as the conventional bone. New concepts of simulation must be designed in the future to test these variations to assess the real influence of osseointegration and grafts in the FEA methodology. Finally, although observed better results related to bicortical techniques, it should be emphasized that these techniques are more complex, being indicated to professionals with experience for proper placement (Kfir et al. 2012), because when not properly placed can cause several problems, including pain, hematoma, swelling, and others (Mazor et al. 2012). 


\section{Conclusion}

Within the limitations of this study, can be concluded that non-axial loads showed higher stress for implant, screw fixation and bone tissue. Bicortical techniques showed lower stress for implant and screw; however, there was slightly higher stress on cortical bone around the implant neck only under loads of higher inclinations $\left(60^{\circ}\right)$.

\section{Acknowledgements}

The authors would like to express gratitude to: Renato Archer Research Center, Campinas, São Paulo, Brazil and Conexão Sistemas de Prótese, Arujá, São Paulo, Brazil.

\section{Disclosure statement}

No potential conflict of interest was reported by the authors.

\section{Funding}

This work was supported by São Paulo Research Foundation FAPESP [grant numbers 2011/01045-2 and 2012/21065-0].

\section{References}

Ahn SJ, Leesungbok R, Lee SW, Heo YK, Kang KL. 2012. Differences in implant stability associated with various methods of preparation of the implant bed: an in vitro study. J Prosthet Dent. 107:366-372.

Baggi L, Cappelloni I, Di Girolamo M, Maceri F, Vairo G. 2008. The influence of implant diameter and length on stress distribution of osseointegrated implants related to crestal bone geometry: a three-dimensional finite element analysis. J Prosthet Dent. 100:422-431.

Binon PP. 1996. The spline implant: design, engineering, and evaluation. Int J Prosthodont. 9:419-433.

Binon PP. 2000. Implants and components: entering the new millennium. Int J Oral Maxillofac Implants. 15:76-94.

Chang SH, Lin CL, Lin YS, Hsue SS, Huang SR. 2012. Biomechanical comparison of a single short and wide implant with monocortical or bicortical engagement in the atrophic posterior maxilla and a long implant in the augmented sinus. Int J Oral Maxillofac Implants. 27:e102e111.

Cooper LF, Reside GJ, Raes F, Garriga JS, Tarrida LG, Wiltfang J, Kern M, Bruyn H. 2014. Immediate provisionalization of dental implants placed in healed alveolar ridges and extraction sockets: a 5-year prospective evaluation. Int J Oral Maxillofac Implants. 29:709-717.

de Faria Almeida DA, Pellizzer EP, Verri FR, Santiago JF Jr, de Carvalho PS. 2014. Influence of tapered and external hexagon connections on bone stresses around tilted dental implants: three-dimensional finite element method with statistical analysis. J Periodontol. 85:261-269.

Frost HM. 2003. Bone's mechanostat: a 2003 update. Anat Record. 275A:1081-1101.

Garcia-Denche JT, Abbushi A, Hernández G, FernándezTresguerres I, Lopez-Cabarcos E, Tamimi F. 2015. Nasal floor elevation for implant treatment in the atrophic premaxilla: a within-patient comparative study. Clin Implant Dent Relat Res. 17:e520-e530.

Goodacre CJ, Bernal G, Rungcharassaeng K, Kan JY. 2003. Clinical complications with implants and implant prostheses. J Prosthet Dent. 90:121-132.

Hsu ML, Chen FC, Kao HC, Cheng CK. 2007. Influence of off-axis loading of an anterior maxillary implant: a 3-dimensional finite element analysis. Int J Oral Maxillofac Implants. 22:301-309.

Huang CC, Lan TH, Lee HE, Wang CH. 2011. The biomechanical analysis of relative position between implant and alveolar bone: finite element method. J Periodontol. 82:489-496.

Ivanoff CJ, Grondahl K, Bergstrom C, Lekholm U, Branemark PI. 2000. Influence of bicortical or monocortical anchorage on maxillary implant stability: a 15-year retrospective study of Branemark system implants. Int J Oral Maxillofac Implants. 15:103-110.

Kfir E, Kfir V, Goldstein M, Mazor Z, Kaluski E. 2012. Minimally invasive subnasal elevation and antral membrane balloon elevation along with bone augmentation and implants placement. J Oral Implantol. 38:365-376.

Lekholm U, Zarb G. 1985. Patient selection and preparation. In: Branemark PI, Zarb G, Albrektsson T, editors. Tissueintegrated prostheses: osseointegration in clinical dentistry. Chicago (IL): Quintessence Publishing; p. 199-211.

Lemos CA, Ferro-Alves ML, Okamoto R, Mendonça MR, Pellizzer EP. 2016. Short dental implants versus standard dental implants placed in the posterior jaws: a systematic review and meta-analysis. J Dent. 47:8-17.

Lorean A, Mazor Z, Barbu H, Mijiritsky E, Levin L. 2014. Nasal floor elevation combined with dental implant placement: a long-term report of up to 86 months. Int J Oral Maxillofac Implants. 29:705-708.

Maeda Y, Satoh T, Sogo M. 2006. In vitro differences of stress concentrations for internal and external hex implantabutment connections: a short communication. J Oral Rehabil. 33:75-78.

Mazor Z, Lorean A, Mijiritsky E, Levin L. 2012. Nasal floor elevation combined with dental implant placement. Clin Implant Dent Relat Res. 14:768-771.

Moraes SL, Pellizzer EP, Verri FR, Santiago JF Jr, Silva JV. 2015. Three-dimensional finite element analysis of stress distribution in retention screws of different crownimplant ratios. Comput Methods Biomech Biomed Eng. 18:689-696.

Papavasiliou G, Kamposiora P, Bayne SC, Felton DA. 1996. Three-dimensional finite element analysis of stressdistribution around single tooth implants as a function of bony support, prosthesis type, and loading during function. J Prosthet Dent. 76:633-640.

Ramos Verri F, Santiago Junior JF, de Faria Almeida DA, de Oliveira GB, de Souza Batista VE, Marques Honório H, Yoshito Noritomi PY, Piza Pellizzer EP. 2015. Biomechanical influence of crown-to-implant ratio on stress distribution over internal hexagon short implant: 3-D finite element analysis with statistical test. J Biomech. 48:138-145.

Santiago JF, Verri FR, Almeida DA, de Souza Batista VE, Lemos CA, Pellizzer EP. 2016. Finite element analysis on influence of implant surface treatments, connection and bone types. Mater Sci Eng C Mater Biol Appl. 63:292-300. 
Şeker E, Ulusoy M, Ozan O, Doğan DO, Şeker BK. 2014. Biomechanical effects of different fixed partial denture designs planned on bicortically anchored short, graftsupported long, or 45-degree-inclined long implants in the posterior maxilla: a three-dimensional finite element analysis. Int J Oral Maxillofac Implants. 29:e1-e9.

Verri FR, Batista VE, Santiago JF Jr, Almeida DA, Pellizzer EP. 2014. Effect of crown-to-implant ratio on peri-implant stress: a finite element analysis. Mater Sci Eng C Mater Biol Appl. 45:234-240.

Verri FR, Cruz RS, de Souza Batista VE, Almeida DA, Verri AC, Lemos CA, Santiago JF Jr, Pellizzer EP. 2016. Can the modeling for simplification of a dental implant surface affect the accuracy of 3D finite element analysis? Comput Methods Biomech Biomed Eng. 15:1-8 [Epub ahead of print].
Verri FR, Santiago JF Jr, Almeida DA, Verri AC, Batista VE, Lemos CA, Noritomi PY, Pellizzer EP. 2015. Three-dimensional finite element analysis of anterior single implant-supported prostheses with different bone anchorages. Sci World J. 2015:321528. doi: http://dx.doi.org/10.1155/2015/321528.

Xiao JR, Li YF, Guan SM, Song L, Xu LX, Kong L. 2011. The biomechanical analysis of simulating implants in function under osteoporotic jawbone by comparing cylindrical, apical tapered, neck tapered, and expandable type implants: a 3-dimensional finite element analysis. J Oral Maxillofac Surg. 69:e273-e281. 